\title{
Farmer Producer Organizations as Farmer Collectives: A Case Study from
}

\section{India $^{1}$}

\section{NaliniBikkina}

Centre for Research in Public Policy

GITAM Institute of Management, GITAM University

Sarvodaya Soudha, GITAM University, Rushikonda, Visakhapatnam 530045, Andhra

Pradesh, India

+91-891-2840317, nalini@gitam.in

\section{Rama Mohana R Turaga}

Public Systems Group, Indian Institute of Management, Ahmedabad

Wing 16F, IIMA Old Campus, Vastrapur, Ahmedabad 380015 Gujrat, India

+91-79-66324956, mohant@iimahd.ernet.in

\section{VaibhavBhamoriya}

Centre for Management of Agriculture, Indian Institute of Management, Ahmedabad Wing 16H, IIMA Old Campus, Vastrapur, Ahmedabad 380015 Gujrat, India

+91-79-66324958, vaibhavb@iimahd.ernet.in

\footnotetext{
${ }^{1}$ We gratefully acknowledge financial support from the Research and Publication division of the Indian Institute of Management Ahmedabad. Susan Matthews, Vinay Chaganti, and AS Sasikala provided research assistance for the paper. Kuldeep Solanki, Suresh Gohil and Ashok Shelar supported with the data collection.
} 


\section{Abstract}

Small and marginal farmers in India have been vulnerable to risks in agricultural production. Several organizational prototypes are emerging to integrate them into the value chain with the objectives of enhancing incomes and reduction in transaction costs. One such alternative is Farmer Producer Organizations (FPOs). We explore the potential of FPOs as collective institutions through a case study of Avirat, one of the first FPOs in Gujarat. Our analysis suggests that FPOs have the potential to provide benefits through effective collective action. The main challenge, however, is to raise sufficient capital that can maximize these benefits. We discuss the implications of our findings to policy.

Keywords: producer organizations, small and marginal farmers, collective action

\section{Introduction}

Small and marginal farmers ${ }^{2}$ constitute the largest group of cultivators in Indian agriculture; 85\% of operated holdings are smaller than or about two hectares and amongst these holdings, 66\% are less than one hectare (Singh, 2012). However, if the increasing number of agricultural suicides among small and marginal farmers (National Crime Records Bureau, 2011) is any indication, these farmers are struggling to survive. While indebtedness is often cited as the immediate reason for distress (Reserve Bank of India, 2006; Satish, 2007), deeper issues are related to vulnerability to risks in agriculture production. These issues include lower scale of operation, lack of information, poor communication linkages with the wider markets and consequent exploitation by intermediaries in procuring inputs and marketing fresh produce, access to and cost of credit (Dev, 2005) and, in isolated cases, aggressive loan recovery practices (Sriram, 2008). In fact, according to the Situation

\footnotetext{
${ }^{2}$ Marginal farmers are farmers who cultivate, as a tenant or owner, up to one hectare of land whereas small farmers are those who cultivate as owner, tenant or sharecropper, agricultural land between one and two hectares (www.rbi.org.in, 2008).
} 
Assessment Survey of Farmers, for many small and marginal farmer households, monthly per capita consumption expenditure is higher than the monthly per capita income (Mishra, 2008).

A variety of approaches have emerged in response to the problems faced by the small and marginal farmers. At the market end of agriculture value-chain, private participation is being promoted through contract farming, particularly after the amendment of the Agricultural Produce Marketing Committee (APMC) Act in 2003. Contract farming involves agricultural production based on an agreement between a corporation and the farmer for production and supply of agreed quantities of a product meeting certain quality standards (FAO, 2014). However, contract farming arrangements tend to exclude small producers (e.g., Gill, 2004; Hazell, 2005; Singh, 2009; Pritchard and Connell, 2011) and in many instances have benefited the buyers at the expense of the producers (Hellin et al., 2009).

The other approach is the facilitation of collective action by small and marginal farmers. Agricultural cooperatives, formed under the Co-operative Credit Societies Act, 1904, has long been the dominant form of farmer collectives; however, the experience with cooperatives point to many limitations that prevent effective collective action. Hence the Indian government has been promoting a new form of collectives called Farmer Producer Organizations (FPOs) to address the challenges faced by the small and marginal farmers, particularly those to do with enhanced access to investments, technological advancements, and efficient inputs and markets (Hellin et al., 2009; Department of Agriculture \& Cooperation, 2013). This paper is a case study of one of the first FPOs formed in Gujarat. We conducted open-ended interviews of 20 members of the FPO, Avirat, operating in Amreli district of Gujarat to explore their experience with the FPO and draw broader implications for FPO as an organizational form to address the issues faced by small and marginal farmers.

\section{Small and marginal farmers and the need for collective action}


Small scale of operations is an important aspect of the problems associated with small and marginal farmers. They require agricultural inputs in small quantities, which they procure from local traders at a price $20-30 \%$ higher than the market rate. Inferior quality of these inputs (Dev, 2005) and long delays in procurement further complicates the problem. Transporting small quantities of produce to urban markets is not viable and they therefore end up selling their produce, particularly perishable commodities to local traders at markedly lower prices (Hegde, 2010). In absence of collectivization, the small scale of operations significantly reduces bargaining power in input procurement as well as sale of output (Kirsten and Sartorius, 2002).

Lack of capital and education, coupled with poor access to adequate information (Gulati et al., 2007), leads to a different set of problems, including the use of obsolete harvesting technologies, affecting the productivity, and poor post-harvest infrastructure (Desai and Joshi, 2014), resulting in 25-30\% of the produce being wasted.

While small and marginal farmers have the advantage of intensive knowledge of local agriculture and low cost access to family labour, they also suffer the disadvantages of high transaction costs in terms of nearly all transactions which are of non-labour nature (Poulton et al., 2010). Inability to access credit and insurance services and vulnerability to vagaries of the climate, pests and other risks further complicate the picture of small and marginal farmers (World Bank, 2008). Recently, greater import competition has added to the difficulties of the smallholders in India (Desai and Joshi, 2014).

In a regional economy faced with stagnation of alternative employment opportunities, the small and medium farmers are forced to continue to cultivate despite repeated crop failures (Rao and Suri, 2006). Also, changing patterns and practices of agriculture initiated by the large farmers are impacting the small and marginal farmers in the rain-fed areas, who started to opt for cash crops and high yielding varieties without sufficiently understanding the 
accompanying risks (Dave, 2012). The past two decades as a consequence have witnessed high levels of indebtedness, increasing unemployment and resultant migration along with a generalized distress in the rural areas of India (Ghosh, 2004; Suri, 2006).

Research increasingly shows that smallholders would be able to substantially increase their incomes from agriculture and allied activities if they participate in markets. As a result, the focus of development has shifted from enhancement of production to market connectivity (Shepherd, 2007). Small Farmers’ Organizations such as cooperatives and FPOs are expected to enhance incomes, reduce costs of input purchases along with transaction costs, create opportunities for involvement in value-addition including processing, distribution and marketing, enhance bargaining power (Welsh, 1997; Ornberg, 2003;Agarwal, 2010), and provide access to formal credit (Braverman et al., 1991).

\section{Cooperatives vs. FPOs as farmer collectives}

Primary Agricultural Credit Societies (PACS) also known as Cooperatives are “...autonomous associations of persons united voluntarily to meet their common economic, social and cultural needs and aspirations through a jointly owned and democratically controlled enterprise” (1995 International Co-operative Alliance Statement on the cooperative identity, incorporated into 2002 International Labor Organization (ILO) Recommendation R. 193 on the Promotion of Cooperatives and the 2001 UN Guidelines aimed at creating a supportive environment for the development of cooperatives (FAO-ILO, 2014)). Cooperatives in India registered with the Registrar of Cooperative Societies have long been prototype farmer collectives, which have started to function consequent to the enactment of the Co-operative Credit Societies Act, 1904. After several amendments, a comprehensive Central legislation called the Multi-State Co-operative Societies Act, 1984 consolidated various legislations governing cooperative societies (Desai and Namboodiri, 1991; Singh and Pundir, 2000). Based on the recommendations of The All India Rural Credit 
Survey Committee Report, 1954 and the Working Group on Co-operative Policy of the Ministry of Food and Agriculture and the approval of the National Development Council (NDC), the Government of India since 1959 began to provide plan and non-plan financial, technical and administrative support to co-operatives directly as well as through the state governments (Dwivedi, 1996).

The experience with PACS across the country suggest that they have largely been state-controlled and, over time, have slipped into the control of local elites (Sharma, 2010). Also, cooperatives focus on welfare rather than on commercial operations (Mondal, 2010). Cooperatives tend to operate as political rather than economic entities with underrepresentation or a total lack of representation of small holders who often do not even receive credit from cooperatives (Frankel, 1978; Sharma, 2010). Political and administrative control in general and the overriding powers of the Registrar of Cooperative Societies to regulate the function in particular have compromised the functioning of cooperative institutions (Department of Agriculture \& Cooperation, 2013). A large number of these cooperatives in the country currently are in a state of financial crisis and are growing increasingly dependent on state subsidy for survival. The Mutually Aided Cooperative Societies Act (MACS), although enacted to overcome some of the limitations of the cooperatives, could not make a mark as not all the states in the country have adopted it and not many cooperatives have migrated to its format (Mondal, 2010).

In this context, the government is promoting the formation of FPOs as a viable alternative to cooperatives. In 2002, the Government of India amended the Companies Act, 1956 by incorporating part IX A, based on the recommendations of the Y.K. Alagh Committee (Mondal, 2010), to provide for producer companies controlled by primary producers which would function along the lines of corporate entities (Bhattacharjee, 2010). Producer Companies are to be registered with the Registrar of Companies as limited 
companies formed with the equity contribution by the members. The day-to-day operations are to be managed by hired professionals under the instructions of the Board of Directors elected by the General Body over a specified tenure (Mondal, 2010). Cooperatives and Producer Organizations differ along several other dimensions as outlined in Table 1.

\section{Insert Table 1 here}

\section{FPOs: A brief background}

The Food and Agriculture Organization (FAO, 2007 as cited in FAO, 2013) notes that “farmers’ and rural producers’ organizations (FOs) refer to independent, non-governmental, membership-based rural organizations of part or fulltime self-employed smallholders and family farmers, pastoralists, artisanal fishers, landless people, women, small entrepreneurs and indigenous peoples.” Producer Companies are also considered to be institutions that have all the significant features of private enterprise while incorporating principles of mutual assistance in their mandate similar to cooperatives (Pustovoitova, 2011). Producer Organizations therefore are supposed to be non-political entities aimed at providing business services to smallholder farmer members, founded on the principal of self-reliance (Onumah et al., 2007).

The basic purpose envisioned for the FPOs is to collectivize small farmers for backward linkage for inputs like seeds, fertilizers, credit, insurance, knowledge and extension services; and forward linkages such as collective marketing, processing, and market-led agriculture production (Mondal, 2010). The Department of Agriculture and Cooperation had issued a policy document titled "Policy and Process Guidelines for Farmer Producer Organizations” in 2013 to encourage the formation of FPOs and laying out indicative guidelines for the formation and performance of these collectives (Department of Agriculture 
\& Cooperation, 2013). The policy guidelines propose an organizational structure of FPOs that is aimed at collaboration with academia, research and extension agencies, civil society organizations and corporations.

While cooperatives entail benefits to farmers via state intervention, FPOs are perceived to empower farmers through collective bargaining along with instilling an entrepreneurial quality to farming, which otherwise is an issue of subsistence alone, particularly for the small and marginal farmers. These collectives, evidently offer ways for small and marginal farmers to participate in the otherwise imperfect markets of the developing countries (De Janvry et al., 1991).

Research evidence increasingly points to opportunities that farmer organizations create for small and marginal farmers to participate more effectively in markets (Stockbridge et al., 2003). Entry barriers to markets were also reportedly reduced through collective action of small and marginal farmers because of enhanced bargaining power (Kherallah et al., 2002; Thorp et al., 2005). Traditionally, small and marginal cultivators sold their produce at the farm gate, often to middlemen at low prices (Fafchamps and Hill, 2005). Producer organizations are reported to be positioned well (Markelova et al., 2009) through innovative approaches to transform market arrangements in favor of marginal and small farmers (International Fund for Agricultural Development, 2001). Heralded as contributors to livelihood enhancement through provision of substantial gains beyond what is possible within the traditional farming context, FPOs can leverage on the strengths of collectives to engage with the government on reforms in agriculture. While these organizational innovations bring about the benefits of collectives into farming, they also entail costs, particularly in situations of market deficiencies and in contexts of unavailability of coordinating mechanisms that link farmers to markets. We explore the benefits and challenges of this new form of organization, as perceived by the members, through a detailed case study. 


\section{Methodology}

\subsection{Study Organization: Avirat}

Shikshan Ane Samaj Kalyan Kendra (SSKK), a network NGO of Sajjata Sangh active since 1980 in Amreli District of Gujarat, had established a farmers’ collective under the title Avirat Agro Business Producer Company Limited. Avirat was chosen for the study since it had been functioning for close to five years and would thereby enable an understanding of the performance of FPOs in the short to medium term.

In 1997, SSKK had initiated work on natural resource management around villages in Khambha as a Project Implementing Agency (PIA). SSKK was instrumental in establishing watershed associations at the village level. Activities related to watershed development came to fruition by 2004-05 (Shelar, 2012). Impressive impacts of watershed development generally reported include significant increase of crop production, generation of additional employment, restoration of water table, socially inclusive watershed committees and accumulation of a community owned development fund (Binswanger-Mkhize and Aiyar, 2003).

Watershed Committees, the existing form of institutions, were primarily formed as Project Implementing Agencies for watershed development activities. Once the watershed development work was completed, farmers felt the need for watershed-plus initiatives to capitalize on the gains of watershed development. Watershed-plus initiatives included land assessment, micro-irrigation, high yielding varieties of seeds, organic cultivation, efforts at reduction in costs of production, capacity-building and skill acquisition for improved methods of cultivation and increase in productivity along with an enhancement of selling price for farm produce through development of market linkages.

However, the members of the Watershed Committees felt that, this kind of institutional form (i.e., the watershed committees) that lacks legal authority is not appropriate 
for watershed-plus initiatives. An alternative institutional form was required to convert these associations into independent and sustainable entities with provisions for input supplies at dealer prices, participation in trading activities, and profit-making ventures by the primary producers. Registration under the Cooperative Act was considered by the members initially. However, considering the perceived grip of vested interests, rampant corruption and interference of political and government functionaries in the operations of cooperatives, the members registered the entity under the Producer Company Act which came into effect from 2005 (Shelar, 2012). As per the provisions of this Act under the Company Law, producer collectives could form companies.

Members therefore decided to form a Producer Company to enable trading and linkages with other public and private corporations. Representatives of watershed associations of 16 villages functioning in the area formed the first Board of Directors. Sixteen hundred farmer beneficiaries enrolled as members from 16 villages in Amreli. Initially, Rs. 5,000 was collected from each watershed association and a Chief Executive Officer was appointed from among the members (Shelar, 2012).

Avirat established an Agro Service Centre to facilitate supply of quality pesticides at affordable prices. The Centre also operates a kiosk to provide information on agricultural products and practices to farmers who visit the Centre to purchase inputs. The Centre serves farmers from more than 50 villages around Amreli. The Centre had further extended its services to the Krushi Mall, a not-for-profit centre, in Khambha. Avirat functions like a developmental agency. However, it is working towards becoming an enterprise by itself rather than to rely on grants. Members, therefore, have chosen the producer company format with the structure outlined as follows (Shelar, 2012).

\section{Insert Figure 1 here}




\subsection{Data Collection and Analysis}

This study uses literature and in-depth interviews with beneficiaries of FPOs in Gujarat. We reviewed the literature on farmer collectives to gain insights into issues and challenges involved in rain-fed agriculture, and the emerging form of agrarian entities called the FPOs. This literature helped the evolution of broad areas of investigation for the in-depth interviews. We conducted a preliminary round of interviews with key informants from Development Support Centre ${ }^{3}$, a social enterprise involved in promoting sustainable livelihoods through participatory natural resource management.

Our data for the study comprises open-ended interviews of 20 Hindi-speaking members of Avirat. We obtained due consent from all the respondents. We conducted in-depth interviews in the form of narratives of the farmer members. The preliminary interviews with the key informants and our review of literature guided the development of the interview protocol used for in-depth interviews.

While the interview protocol served as an approximate guide to interviews, with a focus on overall functioning of the FPO model, we requested the participants to freely narrate perceived benefits of membership of the FPO and the challenges faced by them in realizing the benefits. The protocol was uniform across all informants. However, some farmer members were highly communicative, thereby generating rich narratives, while others were less so. In instances where the respondents were not able to narrate their views freely, follow up questions were posed involving perceived benefits and challenges in the areas of subsidies, credit extension, insurance services, value addition to produce to fetch a higher price, marketing efforts and extension of training - themes which emerged significantly from

\footnotetext{
${ }^{3}$ Sajjata Sangh, the network of NGOs which was instrumental in collectivizing farmers into producer organizations, including AVIRAT, was in turn facilitated by the Development Support Centre.
} 
literature on FPOs, including the policy guidelines. We translated the in-depth interviews, which were conducted in Hindi, into English and transcribed them for coding.

Our framework for coding and analyzing the interview data draws on the FPO service model suggested by the Policy and Process Guidelines for FPOs issued by the Department of Agriculture and Cooperation (Department of Agriculture \& Cooperation, 2013). This service model enlists end-to-end services covering all aspects of farming and comprehensively illustrates an indicative list of services to be offered by the FPOs. These services include financial services, input supply, procurement and packaging, market linkages, insurance, technical support, and networking support. By covering such a wide range of services that a famer collective such as an FPO can provide, this service model serves as an appropriate framework for our analysis given the goal of our study, which is to explore the perceptions of FPO members regarding the services/benefits provided by the FPO and the challenges in realizing the benefits. Annexure 1 provides more details on the services specified in the service model and the coding framework we developed using the service model.

Narratives were coded by two researchers independently to ensure objectivity. The level of agreement between the two coders was $82 \%$. After independently coding the interviews, the two coders met to discuss the disagreements and sorted out the differences. We use the finally agreed upon coding information for our interpretation and analysis.

\section{Findings}

The coding of interview data, as described in the previous section, resulted in the emergence of two predominant themes - input supply and technical services (Figure 2). Approximately one-thirds of the respondents brought up each of these two aspects of FPO service provision during the interviews. In this section, we organize the discussion along these seven services, with a larger focus on the two dominant themes. We discuss and 
analyze the views expressed by the farmer members of Avirat to draw broader implications for the functioning of FPOs.

\section{Insert Figure 2 here}

\subsection{Input supply services}

As shown in Figure 2, 34\% of our respondents mentioned input supply services in the context of Avirat's services. According to our respondents, Avirat facilitates purchase of government approved seeds with price advantages of up to $10-15 \%$ for the Kharif and the Rabi seasons, particularly seeds of Bt Cotton, groundnut, and cumin, pesticides, and other inputs like farm implements and equipment to the tune of up to 50\%. Avirat is able to provide these subsidies through negotiation with input suppliers on a bulk basis for price advantage. Farmer Members of Avirat have reported a collective benefit of up to Rs. 10-15 lakh through lower input prices.

Our interviews reveal that Avirat provides inputs through two types of arrangements. The Avirat Seed Foundation, which is a public-private partnership (PPP) between the stateowned Gujarat Rajya Beej Nigam (Gujarat Seed Corporation) and Reliance Industries, functions as a seed bank, providing low priced quality seeds especially for cotton, groundnut, castor, and cumin. Farmer members who require as little as half a bag of seeds have access to certified seeds from this seed foundation. According to our respondents, the seeds supplied through the foundation are not only cheaper than the market price but are more reliable in terms of quality. The farmers report that buying seed or pesticide in the open market is expensive because merchants do not price these inputs in a transparent manner.

While the Avirat Seed Foundation deals with supply of seeds, Krishi Malls, a chain of regional outlets across rural Gujarat, supply a variety of other products, including pesticides, 
farm implements, and other equipment such as sharp cutters, shredders, tractors, grinding machines, pumps, and harvesters. As Madhurbhai states, the subsidies on the farm equipment can go up to $50 \%$ on some items:

Avirat facilitated the use of sprinkler irrigation and the use of equipment like sharp cutter and harvester. For these equipment a 50\% subsidy [price advantage] is offered. Avirat in turn gets commission.

Our discussion suggests that our respondents perceive significant benefits in the form of lower input prices because of their membership in Avirat. Instead of solely depending on the government subsidies, the lower input prices are generated using the bargaining ability of the collective body, generating benefits to everyone. The lower input prices are perhaps possible also because of the innovative mechanisms such as PPP in the form of Gujarat Seed Foundation and Krishi Malls that Avirat has been able to institute for supplying farm inputs. By providing farm inputs at fair prices, Avirat seems to be catering to an important requirement of the small and marginal farmers who often report their lack of financial capability to procure these inputs from the open market (Hegde, 2010).

Although there are clear benefits generated in terms of lower input prices on seeds and farm equipment, a problem pointed out by the respondents is the inability of Avirat to supply subsidized fertilizers. While cooperatives can provide subsidy on fertilizers, FPOs cannot market fertilizers. The licensing policy of the Ministry of Chemicals and Fertilizers, Government of India, specifically, the Fertilizer Control Order, 1957/1985, enforced by the state governments prohibits FPOs from marketing fertilizer. The 'Principal Certificate' can only be issued to Cooperatives (Bhattacharjee, 2010). Consequently, even on demand from farmers that the FPOs supply fertilizer through the Gujarat State Cooperative Marketing Federation Ltd, FPOs could not venture into fertilizer subsidies. Babubhai Senjalya comments that: 
Subsidy for pesticide is a benefit with [membership of] Avirat. However, subsidy for fertilizer is offered [only] through membership of cooperatives.

\subsection{Technical services}

The technical services that Avirat provides include a variety of training programmes and information dissemination activities. Avirat provides crop-based training to the farmers at regular intervals. The company provides training on crop development and disease prevention, particularly for groundnut, cotton, and wheat along with seed cultivation. Crop demonstrations by Avirat on the variety of crops available for their farms facilitate farmers' choice of crops. Farmer-to-farmer learning is also encouraged. Water harvesting awareness is perceived as one of the most significant benefits of membership of Avirat. According to the respondents, there has been a marked increase in the use of drip and sprinkler irrigation. This resulted in substantial water saving and decrease in the salinity of soil. Members also receive training in the use of farm equipment like tractors. According to Ratibhai:

Another unique activity of Avirat, which had benefited members immensely, is the organization of exposure visits. Avirat, for instance, organized an exposure visit to Ralegaon, which is known for its watershed development practices.

Periodic training programmes seem to have significantly impacted on and off-farm agricultural practices. This seems to have brought about a qualitative change to farming practices. One respondent, Kalubhai Vora, believes that the training may have even improved the income for some members.

As Sarpanch of the Village I could also help enhance the income of other farmers in the village through proactively seeking training programmes from Avirat. As a result of the efforts of Avirat there has been a decline in out- 
migration of farmers from the village. As farmer members, they are interested in survival in the village to begin with.

The other major technical service that Avirat provides is information dissemination. Avirat uses information technology, particularly the internet, extensively to facilitate timely (2-3 times in a month) information needed for farm operations. The nature of information disseminated by Avirat includes economic information such as market trends, prices of commodities in the market and varieties within commodities, stock positions, and minimum support prices for various crops; crop-related information such as new seed varieties, particularly for cotton (3-4 varieties) and groundnut; information on weather, for example, rainfall forecast for June and July; information on agricultural practices such as new irrigation methods with emphasis on drip, sprinkler, and electronic methods and successful new agricultural practices; information related to new technology, innovations in farm implements and equipment. Information along these dimensions is directly passed on to the farmers through mobile messaging three to four times in a month.

Clearly, Avirat's training and information dissemination activities have been significantly benefiting the small and marginal farmer members, who on their own may not be able to access these resources easily. However, it appears that there are many areas where there is a significant scope for improvement.

First, an initiative to encourage environmentally safer alternatives to fertilizers, such as vermicompost and intercropping, have not been successful to the desired levels due to the lack of awareness regarding the benefits of these alternatives vis-à-vis fertilizers. Similarly, apprehension regarding hybrid seeds has been creating barriers in their wider use. Kanubhai Nasit notes that: 
Farmers are apprehensive about hybrid seeds. They need to be educated about the advantages of hybrid seeds with reference to greater yields and less usage of water. Hybrid seeds are considered fake by some farmers.

The second area that requires enhanced education and training, according to our respondents, is regarding the use of pesticides. First, there is a need to maintain a record of the amount and kind of subsidized pesticides being used by individual farmers. Farmers end up using an overdose of pesticides and consequently deprive other farmer members from getting the required dosage. Farmers also mix pesticides without adequate knowledge of the consequences.

Training is a significant area where Avirat reportedly made a remarkable difference to its members. Sustainability of this service however would require periodic assessment of training requirements and subsequent targeting of training programmes. These assessments might benefit from a more participatory approach, involving the farmer members, to identify the training needs.

\subsection{Financial services}

Extension of credit is critical for small farmers but is not being taken up by Avirat for two reasons. First, regulatory provisions do not allow organizations such as Avirat to disburse loans. Second, Avirat does not have enough capital on its own to disburse loans. The alternative is to borrow loans at high interest rates, which make the loans unaffordable to the small farmers. Hamirbhai Dubhi states:

I have not visited nor taken part in the activities of Avirat. Cooperatives advance loans to the farmers. This is the reason that membership in cooperatives is being continued. I have not specifically benefited from Avirat in any manner till now. 
Avirat, however has ventured into discussion with National Bank for Agriculture and Rural Development to work out collaboration in the area of loan extension to farmers.

Unavailability of collateral free farm loans had been a concern for small and marginal farmers. Non-extension of farm credit had often been cited as an important reason for agrarian distress (Sriram, 2008). This is even more so in rainfed areas where production is unpredictable due to the vagaries of the monsoon. Farmers, thereby, expect extension of financial support from organizational entities and may even judge the efficacy of institutional forms with reference to the provision of credit or otherwise. The Avirat model has not been successful in extending credit to its members.

\subsection{Procurement and packaging}

Although creating market linkages is one of the primary objectives of FPOs, our interviews reveal that Avirat has not been able to make progress in collective marketing of farm produce. Unavailability of sufficient storage and other infrastructure and more importantly, lack of capital to create value addition to the farm produce appear to be the barriers to establishing mechanism for collective marketing. For example, currently, ginning mills purchase cotton at low prices. Avirat could enhance the value of cotton if collective facilities for ginning are made available to the farmers.

Self Help Groups need to be roped into the activities of Avirat as felt by farmer members, to create value addition of the farm produce, thereby securing and enhancing farm incomes. Members for instance suggested that women members of self-help groups may process groundnut to powder or candy, thus fetching higher price and enhancing shelf life, making the product less perishable. Women could play a potential role in grading yields of crops like groundnut, which would help fetch higher prices for better quality of produce. While members did mention that bringing self-help groups into Avirat for value addition had 
been thought about and is being encouraged, the idea had not seen implementation. As Rameshbhai discloses:

[The] product is not being put through value addition at the level of Avirat, although it would be a potential benefit that Avirat can work on.

\subsection{Insurance}

One significant and pioneering contribution of Avirat to farming is the provision of weather insurance to the farmers at affordable premiums. Crop insurance in India had otherwise been highly subsidized by the state and distributed unequally (Ghosh et al., 2008). Since agriculture in this region is rainfed, erratic monsoons have resulted in severe losses and indebtedness, at times leading to suicides by farmers. The weather insurance innovation by Avirat is aimed at saving similar disasters in the future. However, once hailed as significant, the weather insurance initiative is not being favorably received by some farmer members due to lack of awareness about insurance as a safety net. Small farmers also perceived the premium to be paid as high and unaffordable. Premium was gradually increased to Rs. 750 per year and a large number of small and marginal farmers discontinued payment of premium and are no longer covered. As Bhaveshbhai narrates:

Varsha Bima is extended by Avirat. However, premium had become expensive and I have discontinued participation. Premium to be paid now is Rs. 750 per year.

Farmer members discontinued payment of premiums as they seem to consider premium to be an investment with no returns when the monsoon is good and timely. The challenge for Avirat here seems to involve sustainability of the weather insurance initiative with special emphasis on awareness creation and demystification of the insurance process from payment of premiums to the final payouts.

\subsection{Market linkages}


Farmer members of Avirat reported coming together to form informal networks, pooling produce and transporting the same to the city markets, thereby increasing the selling price of the produce. This is consistent with the findings in the literature, which suggest that, farmers' associations are preferred over individual farmers for entering into a contract to supply vegetable and dairy products (Landy, 2013). Kalubhai Vohra states that:

Due to training of Avirat, attempts were being made to pool produce of the farmers in the village to be transported and sold in the urban areas at higher prices, thereby eliminating middlemen. This resulted in fetching higher prices for the produce of many farmers in the area.

One respondent suggested that, in addition to market linkages, Avirat may also organize farmer melas seasonally to create visibility and enhance income of the farmers through sale of fresh produce directly to local consumers. The process however is expensive, according to Avirat. Attempts at National Commodity and Derivatives Exchange Limited linkages did not materialize.

Avirat seems to be in the process of scaling up its marketing services. While futures trading through NCDEX linkages are being talked about, farmers might be wary of speculation. Also, since the procurement, packaging, and value-addition have not scaled up, entry barriers seem to come into place for the produce of the farmer members in up-scale markets.

\subsection{Networking support}

Avirat is reported to have facilitated networking among farmers. Avirat is networking with agricultural universities in the state to update the farmers on latest farm technology and agricultural practices, thereby facilitating transfer of knowledge from lab to the farm. Avirat, in fact, was instrumental in introducing new high yielding varieties of groundnut and cotton in the Amreli area, a consequence of its networking support function. Avirat proactively 
encourages interaction among its members and collaboration with other FPOs. Ashokbhai mentions that:

Avirat and Maha Gujarat were FPOs started on a trial basis. The two actively collaborate with one another.

Shyamjibhai Sarvaiyatoo reported that:

Membership of Avirat facilitated networking among farmers which lead to improved farmer-to-farmer learning.

Farmer members have benefited directly and indirectly through the networking services offered by Avirat. While collaboration with agricultural universities helped availability of agricultural research to enhance quality of farming, networking with other collectives had brought in farmer-to-farmer knowledge sharing, thereby also creating social networks.

\section{Discussion and Implications}

Our interviews with the farmer members of Avirat suggest that the FPO, as an institution for collective action, has been successful on many fronts but also faces significant challenges. The success in bargaining for lower input supply prices, the ability to pool produce to get higher price for outputs, and the innovative methods in training and information dissemination have resulted in significant benefits to the members in terms of enhancement of their incomes. The main challenge, however, appears to be the inability to access capital, which, to some extent, is undermining the advantages of collectivization. In our interviews, the lack of capital has emerged as a barrier for providing many services - for example, extension of credit to members and provision of infrastructure for value addition.

The case of Avirat points to a need for the FPOs to evolve a business model that can raise enough capital to maximize the benefits of collectivization. FPOs appear to be positioned between PACS and wholly private participation such as contract farming along the 
state-market continuum. While cooperatives benefit from the government support for access to capital, market-driven arrangements such as contract farming can raise capital in the market because of their focus on profit. In the case of FPOs such as Avirat, profits generated through arrangements such as krishi malls appear to be of insufficient scale to meet the capital requirements. Also, borrowing the capital from the market is unviable for these organizations because of the relatively small scale of operations.

How should the FPOs enhance their access to capital? The obvious place to start is the government support. The good news is that the concern regarding the need for greater access to capital is already being reflected in the policy on FPOs. The Preamble to the National Policy for the Promotion of Farmer Producer Organizations outlines the role of financial institutions including NABARD in supporting FPOs to include extension of credit for infrastructure investment and working capital requirements. The process guidelines make special mention of these collectives as nodal points for credit transmission along with outlining loan provision as a key financial service to be offered under the FPO Service Model (Department of Agriculture \& Cooperation, 2013). Recently, Small Farmers Agribusiness Consortium (SFAC) and the Reserve Bank of India (RBI) have formulated policies to extend credit to producer organizations (Singh, 2012).

The FPOs might also do well to learn from the experience in other contexts where producer groups used collective action to overcome credit barriers. An interesting example is the case of potato farmers in Uganda where the producers established a savings and credit cooperative (SACO) with the help of the Government of Uganda (Kaganzi et al., 2009). The savings of the producers are deposited in SACO and the pooled savings are disbursed as credit to the members. The interest generated by the credit bring additional revenues to the cooperative, further enhancing their ability to provide credit to their members. 
Our study has other implications for policy. First, if FPOs are perceived as a promising approach to improving the state of small and marginal farmers, there is a need for the government to extend the benefits of cooperatives to FPOs as well. In our interviews, the issue of fertilizer subsidy turns out to be quite important for the members of Avirat. Given that fertilizers constitute 23\% of the cost of cultivation in rural India (Mehta, 2009), the benefits of a subsidy on fertilizers is understandable. At the same time, it is important for the government to work with the FPOs to promote more environmentally sustainable inputs such as natural and bio-fertilizers by creating awareness and perhaps providing technical assistance to the FPOs.

Second, our case study finds some support for the government's intention to form FPOs as an aggregation of a set of smaller Farmer Interest Groups (FIGs) (Department of Agriculture \& Cooperation, 2013). Although our interviews do not focus on the process of formation of Avirat, the relative success of Avirat indicates that aggregating smaller existing grassroots agricultural institutions like watershed committees into producer organizations might be beneficial for effective collective action.

Empirical research sheds some insights on the reasons for the likelihood of success for such an approach to the formation of FPOs. It is easier for smaller groups to work cohesively with a specific purpose and there is evidence that when these groups come together as a producer organization, the resultant dynamics seem to bring the new agglomeration together with relative ease (Shelar, 2012). Also, organizations that emerged as a result of federating from existing smaller groups offer ways to combine small base collectives with economies of scale (Markelova et al., 2009). For instance, the success of a federation of cocoa producers in Bolivia to scale up their marketing opportunities is attributed, at least in part, to the institutional form that was built upon prevailing forms of collective functioning (Bebbington, 1996). A sense of group loyalty, strong social ties and 
ownership may determine successful functioning of federated institutions built from smaller groups. Marked social affinities among members as a consequence of belonging to smaller groups are conducive for functioning of subsequent aggregations (Agarwal, 2010).

Finally, our case study tentatively highlights the potential need for a democratic, participatory decision making process for FPOs. Although our study did not focus sufficiently on the extent and nature of the participation of the individual members in the FPO’s decision making, we identify at least one area - the training need assessment - where the FPO members would likely benefit from a participatory approach. Our respondents identified training and information dissemination as a key benefit of FPO membership, but at the same time expressed a need for better assessment of training needs. A participatory approach in which the training needs are identified based on extensive consultations with the producer members might be beneficial.

Facilitating agencies such as Sajjata Sangh can hand-hold organizations like Avirat in the creation and continuance of an ongoing interaction between the members and the Board of Directors, thereby creating a truly participatory and bottom-up approach. Periodic field visits by the Board of Directors and regular regional and sub-regional farmer conferences would create and nurture continuous flow of communication between individual farmer members and the Board, thereby institutionalizing a truly participatory decision making process.

\section{Conclusion}

While the experience of Avirat puts forth a strong case for extending support to member-based farmer collectives, our claims with reference to the extent of their generalization are limited, as they are based on a single case study. FPO membership may in reality increase the risk profile of farmers in terms of a forced adoption of market-oriented agricultural production. An example is the shift to cash crops vis-à-vis food crops by farmer 
members of FPOs. Future research could investigate the extent to which this type of organizational structure could lead to such unintended outcomes. While FPOs have received policy support, are being promoted by multilateral development institutions, and are increasingly visible as possible alternatives to other institutional forms in Indian agriculture, further critical and empirical analysis is required into this concept, particularly with reference to the structure and functioning of these organizations vis-à-vis the objectives laid out for these institutional forms. Metrics also need to be devised for evaluating performance of these organizations along economic and social dimensions. Further research with special reference to long-term impact of FPOs and their organizational flexibility to meet the requirements of diverse agricultural systems is essential to establish the broader significance of this organizational form and to understand the viability and scalability to a large number of smallholders. 


\section{Annexure 1: FPO Service Model and Coding Framework}

The service model of the FPOs is delineated in the Policy and Process Guidelines as including:

\section{Financial Services}

NABARD along with other financial institutions including cooperative banks and State Financial Corporations would be directed to extend short and medium term credit towards provision of infrastructure and working capital requirements of FPOs. DAC aims at total financial inclusion of FPO members along with linkages to Kisan Credit Cards. The FPOs are to provide credit for crops and farm machinery, in addition to provision of insurance services including life and crop insurance.

Input Supply

State governments would be directed to make provisions for issue of licenses to trade in seed, fertilizer, farm machinery and pesticides and for certification as producers of seed, saplings and plant material on par with cooperatives.

Procurement and Packaging

FPOs would be considered eligible institutions by the NAFED to act on its behalf to undertake purchase operations through price support. Food Corporation of India (FCI) and the state governments would be encouraged to include FPOs as agencies for procurement operations under the Minimum Support Price (MSP).Support to the FPOs would be extended to develop forward linkages through storage, post-harvest processing, value addition and packaging for enhanced access to fair and remunerative markets.

\section{Market Linkages}

State governments would be directed by the DAC to permit the FPOs to sell agricultural produce at the farm gate, through direct procurement by FPO owned agencies and through contract farming with bulk buyers, including linkages to market aggregators. The 
objective of marketing services in addition to the maintenance of marketing information system by the FPOs is to enable farmer members to save time, transaction costs and weighing losses in addition to prevention of distress sales and adverse impact of price fluctuations. Insurance

FPOs would be encouraged to provide for risk management through access to insurance services including crop and weather based insurance apart from life insurance and general insurance for farm equipment.

Technical Support

Support in terms of identification of appropriate crops to the agro-climatic context too would be provided through the FPOs. Support in terms of knowledge and lab-to-field dissemination and dissemination of best practices, including post-harvest processing practices for value enhancement in addition to capacity building would be extended through Farmer Field Schools.

Networking Support

State governments would be encouraged to use FPOs to implement programmes like the RashtriyaKrishiVikasYojana, National Food Security Mission through linkages with Agricultural Technology Management Agency and the like. FPOs would be supported to evolve as nodal points for pooling of produce, transmission of farm technology, input supply and credit to leverage better prices. As federated organizations, FPOs are deemed to enhance backward and forward linkages through negotiating power, including linkages with financial institutions and linkages between farmers, processors, traders, retailers, transport services and customers (Department of Agriculture and Cooperation, 2013).

Insert Table A1 here 


\section{References}

Agarwal, B. (2010) 'Rethinking agricultural production collectivities', Economic and Political Weekly, 45(9): 64-78.

Bebbington, A. (1996) 'Organizations and intensifications: Campesino federations, rural livelihoods and agricultural technology in the Andes and Amazonia', World Development, 24(7): 1161-1177.

Bhattacharjee, S. (2010) 'Experience of Producer Organizations: A Case of Five Producer Companies', Financing Agriculture, 42(7): 12-21.

Binswanger-Mkhize, H. P. and Aiyar, S. S. A. (2003) 'Scaling up community-driven development: theoretical underpinnings and program design implications', World Bank Policy Research Working Paper 3039.

Braverman, A., Guasch, J. L., Huppi, M. and Pohlmeier, L. (1991) 'Promoting rural cooperatives in developing countries: the case of sub-Saharan Africa', World Bank discussion papers (USA). Washington, D.C., World Bank.

Dave, P. (2012) 'Making Information Reach on Time: A Case of Information Revolution', Strengthening Civil Society Participation in National Resource Management: Experience of Sajjata Sangh-A Network of NGOs in Gujarat, pp. 19-29. Ahmedabad.

De Janvry, A., Fafchamps, M. and Sadoulet, E. (1991) 'Peasant household behavior with missing markets: Some paradoxes explained', Economic Journal, 101(409): 14001417.

Department of Agriculture \& Cooperation (2013) 'Policy and Process Guidelines for Farmer Producer Organizations'. Ministry of Agriculture, Government of India.

Desai, B. and Namboodiri, N. (1991) 'Comparative performance of farmers service societies and primary agricultural cooperative credit societies', Vikalpa, 16(4): 23-30. 
Desai, R. M. and Joshi, S. (2014) 'Can Producer Associations Improve Rural Livelihoods? Evidence from Farmer Centres in India', The Journal of Development Studies, 50(1): $64-80$.

Dev, S. M. (2005) 'Agriculture and rural employment in the budget', Economic and Political Weekly, 40(14): 1410-1418.

Dwivedi, R. C. (1996) 'Role of co-operatives in rural economy', Indian Journal of Agricultural Economics, 51: 713-727.

Fafchamps, M. and Hill, R. V. (2005) 'Selling at the Farmgate or Traveling to Market', American Journal of Agricultural Economics, 87(3): 717-734.

FAO-ILO. (2014). 'Cooperatives \& Producers' Organizations: Food, Agriculture \& Decent Work: ILO \& FAO working together', Accessed on 27 May 2013 from http://www.fao-ilo.org/fao-ilo-coop/

FAO. (2014). 'Contract Farming Resource Centre', Accessed on 13 May 2014 from http://www.fao.org/ag/ags/contract-farming/faq/en/

Frankel, F. R. (1978) 'India's Political Economy: The Gradual Revolution 1947-77'. New Delhi: Oxford University Press.

Ghosh, J. (2004). 'Final Report of the Commission on Farmers’ Welfare', Accessed on from http://www.macroscan.org/pol/apr05/pdf/Full_Report_Commission_Farmer_AP.pdf

Ghosh, N., Bhatt, Y. and Yadav, S. (2008) 'Impact of Crop Insurance on Agricultural Productivity: Reviewing the performance of India’s NAIS', in Growth, I. o. E. (ed) Discussion Paper Series No. 128/2008. University of Delhi Enclave (North Campus), India.

Gill, S. S. (2004) 'Small farmers and Markets', Economic and Political Weekly: 2356-2358. 
Gulati, A., Minot, N., Delgado, C. and Bora, S. (2007) 'Growth in High-Value Agriculture in Asia and the Emergence of Vertical Links With', Global supply chains, standards and the poor: $91-108$.

Hazell, P. B. (2005) 'Is there a future for small farms?', Agricultural Economics, 32(s1): 93101.

Hegde, N. G. (2010) 'Development of Value Chains for Sustainable Agriculture', Financing Agriculture, 42(7): 26-28.

Hellin, J., Lundy, M. and Meijer, M. (2009) 'Farmer organization, collective action and market access in Meso-America', Food Policy, 34(1): 16-22.

International Fund for Agricultural Development. (2001). 'Rural Poverty Report 2001: The Challenge of Ending Rural Poverty', Accessed on 2 June 2014 from http://www.ifad.org/poverty/

Kaganzi, E., Ferris, S., Barham, J., Abenakyo, A., Sanginga, P. and Njuki, J. (2009) 'Sustaining linkages to high value markets through collective action in Uganda', Food Policy, 34(1): 23-30.

Kherallah, M., Delgado, C. L., Gabre-Madhin, E. Z., Minot, N. and Johnson, M. (2002) Reforming agricultural markets in Africa, Baltimore and London: The John Hopkins University Press.

Kirsten, J. and Sartorius, K. (2002) 'Linking agribusiness and small-scale farmers in developing countries: is there a new role for contract farming?', Development Southern Africa, 19(4): 503-529.

Landy, F. (2013) 'From Trickle Down to Leapfrog', Economic \& Political Weekly, 48(24): 43.

Markelova, H., Meinzen-Dick, R., Hellin, J. and Dohrn, S. (2009) 'Collective action for smallholder market access', Food policy, 34(1): 1-7. 
Mehta, R. (2009) 'Situation Assessment Survey for farm sector policy formulation", paper presented at the FAO Expert Consultation on Statistics in Support of Policies to Empower Small Farmers, Bangkok, 8-11 September 2009.

Mishra, S. (2008) 'Risks, farmers' suicides and agrarian crisis in India: Is there a way out?', Indian Journal of Agricultural Economics, 63(1): 38-54.

Mondal, A. (2010) 'Farmers’ Producer Company (FPC) Concept, Practices and Learning: A Case from Action for Social Advancement.', Financing Agriculture, 42(7): 29-33.

National Crime Records Bureau (2011) 'Accidental Death and Suicides in India'. Ministry of Home Affairs, Government of India.

Onumah, G., Davis, J., Kleih, U. and Proctor, F. (2007). 'Empowering smallholder farmers in markets: Changing agricultural marketing systems and innovative responses by producer organizations', Accessed on 2 June 2014 from http://mpra.ub.unimuenchen.de/25984/1/MPRA_paper_25984.pdf

Ornberg, L. (2003) 'Farmers' Choice: Contract Farming, Agricultural Change and Modernisation in Northern Thailand', 3rd International Convention of Asia Scholars (ICAS3), Singapore, August, pp. 19-22.

Poulton, C., Dorward, A. and Kydd, J. (2010) 'The future of small farms: New directions for services, institutions, and intermediation', World Development, 38(10): 1413-1428.

Pritchard, B. and Connell, J. (2011) 'Contract farming and the remaking of agrarian landscapes: Insights from South India's chilli belt', Singapore Journal of Tropical Geography, 32(2): 236-252.

Pustovoitova, N. (2011) 'Producer Company as an Institutional Option For Small Farmers in India', Lunds Universitet.

Rao, P. N. and Suri, K. (2006) 'Dimensions of agrarian distress in Andhra Pradesh', Economic and Political Weekly: 1546-1552. 
Reserve Bank of India. (2006). 'Report of the Working Group to Suggest Measures to Assist Distressed Farmers', Accessed on 2 June 2014 from http://rbidocs.rbi.org.in/rdocs/PublicationReport/Pdfs/78889.pdf

Satish, P. (2007) 'Agricultural credit in the post-reform era: A target of systematic policy coarctation', Economic and Political Weekly: 2567-2575.

Sharma, P. (2010) 'Promoting Farmer Producer Organizations to Mitigate Risk and Improve Market Access: Lessons and Challenges', Financing Agriculture, 42(7): 22-25.

Shelar, A. (2012) 'Making of a Farmers' Company: Avirat Agro Business Producer Company Limited', Strengthening Civil Society Participation in National Resource Management: Experience of Sajjata Sangh-A Network of NGOs in Gujarat. Ahmedabad.

Shepherd, A. (2007). 'Approaches to linking producers to markets: A review of experiences to date', Accessed on 2 June 2014 from ftp://ftp.fao.org/docrep/fao/010/a1123e/a1123e00.pdf

Singh, K. and Pundir, R. (2000) Co-operatives and Rural Development in India: Institute of Rural Management.

Singh, S. (2009) Organic Produce Supply Chains in India: Organisation and Governance: Allied Publishers.

Singh, S. (2012) 'New markets for smallholders in India-Exclusion, policy and mechanisms', Economic and Political Weekly, 47: 95-105.

Sriram, M. (2008) 'Agrarian distress and rural credit: Peeling the onion', in Datta, S. and Sharma, V. (eds) State of India's Livelihoods: The 4 P Report, pp. 171. New Delhi, Access Development Services. 
Stockbridge, M., Dorward, A., Kydd, J., Morrison, J. and Poole, N. (2003). 'Farmer Organizatios for Market Access: An International Review', Accessed on 2 June 2014 from http://r4d.dfid.gov.uk/pdf/outputs/r8275_040518_intlrev_fo_mktaccss.pdf

Suri, K. (2006) 'Political economy of agrarian distress', Economic and Political Weekly: 1523-1529.

Thorp, R., Stewart, F. and Heyer, A. (2005) 'When and how far is group formation a route out of chronic poverty?', World Development, 33(6): 907-920.

Welsh, R. (1997) 'Vertical Coordination, Producer Response, and the Locus of Control over Agricultural Production Decisions', Rural Sociology, 62(4): 491-507.

World Bank. (2008). 'World Development Report: Agriculture for Development', Accessed on 2 June 2014 from

http://siteresources.worldbank.org/INTWDRS/Resources/477365-

1327599046334/WDR_00_book.pdf 
Table 1: Significant differences between Producer Companies and Cooperatives

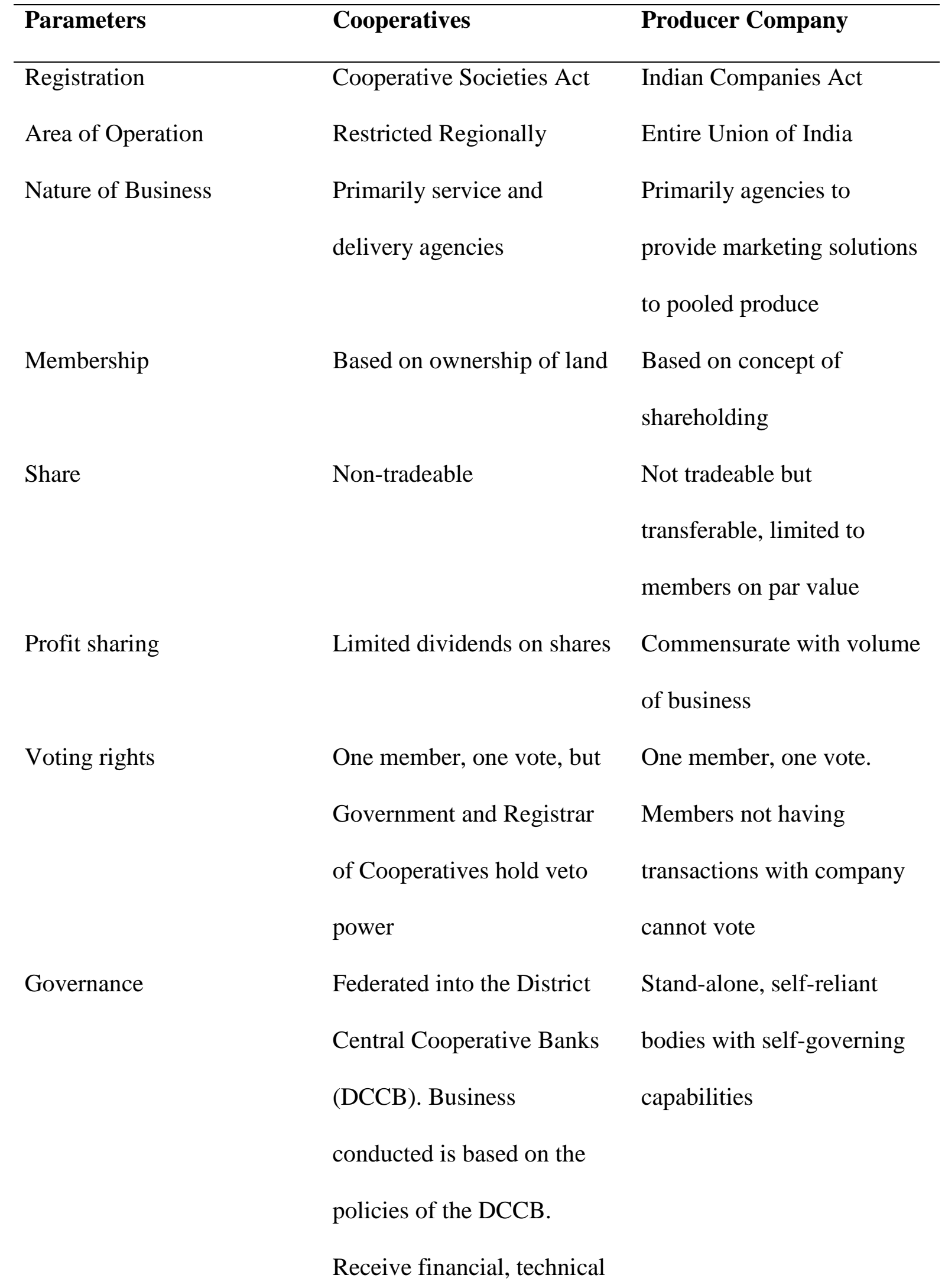




\begin{tabular}{lll}
\hline Parameters & Cooperatives & Producer Company \\
\hline and administrative support & \\
from the government & \\
Reserves & Created if there are profits & Mandatory \\
Borrowing Power & Restricted to loans granted & More freedom and more \\
& and disbursed by the & alternatives available. FPOs \\
& cooperative bank to which & are allowed to raise capital \\
the PAC is linked & from external sources \\
Relationship with other & Transaction based & Producers and \\
business and non-profit & & corporate/non-profit entities \\
entities & & can together float a producer
\end{tabular}

Sources: Department of Agriculture and Cooperation (2013). Policy and Process Guidelines for Farmer Producer Organizations. New Delhi; Dwivedi, R.C. (1996). Role of Co-operatives in Rural Economy. Indian Journal of Agricultural Economics, 51(4), 712-727; Mondal, A. (2010). Farmers' Producer Company (FPC) Concept, Practices and Learning: A Case from Action for Social Advancement. Financing Agriculture, 42(7), 29-33; and National Advisory Council (2012). Draft Recommendations of the Working Group on Enhancing Farm Income for Small Holders through Market Integration. New Delhi: Author. 
Table A1: Coding Framework for Analyzing Interview Data

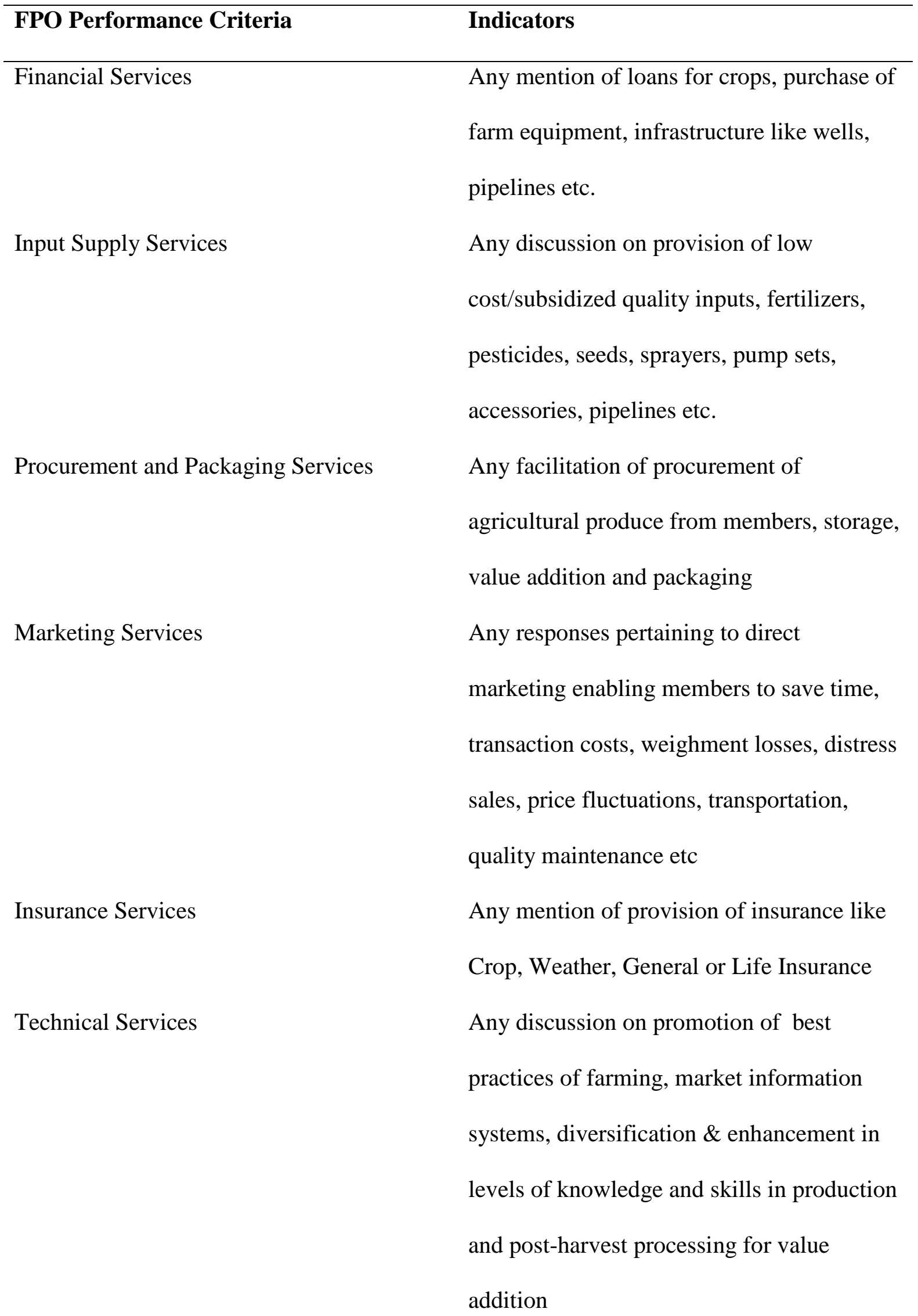


FPO Performance Criteria

Networking Services
Indicators

Any response with reference to making

channels of information accessible,

facilitation of linkages of producers,

processors, traders, consumers and the

government. 


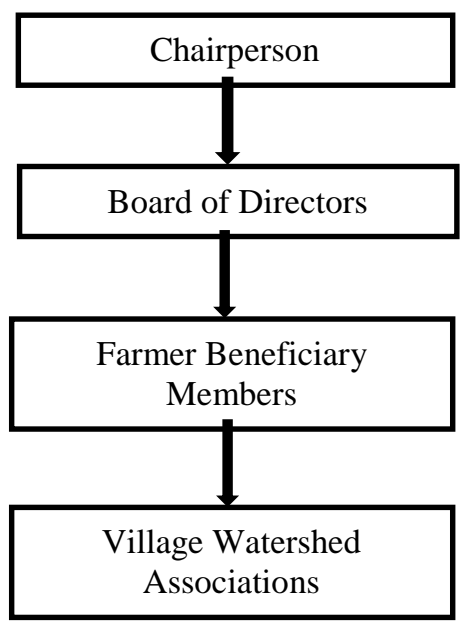

\section{Figure 1: Organizational Structure of Avirat}

Source: Shelar, A. (2012). Making of a Farmers’ Company: Avirat Agro Business Producer Company Limited. In. Strengthening Civil Society Participation in Natural Resource Management: Experiences of Sajjata Sangh. A Network of NGOs in Gujarat. Ahmedabad: Sajjata Sangh. 